\title{
SOCIO-ECONOMIC APPROACH TO THE STUDY OF FOREIGN ECONOMIC RELATIONS OF THE REGION
}

Zh. A. Mingalyova, E. Y. Loseva, E. D. Oborina

The article is devoted to considering of socio-economic approach to the study of foreign economic relations of the region, the main statements of the approach are formulated. The indices of foreign trade activities of Sverdlovsk region, the volume of foreign investment are analyzed, countries which can be region's strategic partners are identified. In the article the tasks and directions of regional foreign policies to improve competitiveness and socio-economic development are defined.

The problem of enhancing release of the Russian regions on a global level is now more than ever. Subject of the Federation represents the level of administrative and managerial hierarchies that best defines the positioning and specification of the competitive advantages of the country with a federal structure. Country's competitiveness as a whole are assembled from competitiveness of each Russian region. Interregional economic relations become more closely intertwined with foreign economic and regions increasingly are approved in the category of full partners in international economic relations [6].

Socio-economic approach to the study of a region has been actively developed since the 60-70ies of XX century [4, p. 54-85]. This approach is theoretically put the level and quality of life of the population in dependence on the functioning of the economy of the region. In this approach the region is a socio-economic complex (system), the basic units (components) of which (material production,

\footnotetext{
${ }^{1}$ The article is completed with financial support from the grant of Russian fund of the humanities of Ural №11-12-66018a/Y «Estimation and forecasting of influence of foreign economic relations of Ural with Chinese provinces on socioeconomic development of the region».
}

social) are balanced and provide stability for the region. Based on this definition, we can formulate the following principles of socio-economic approach to the study of IER (international economic relations) of the region:

1. Region is an open socio-economic system with a built in it foreign economic complex.

2. IER is a tool to improve the socio-economic development and regional competitiveness.

3. IER of region are effective in the case when help improve the level and quality of life.

As foreign economic activity intensifies consideration of socio-economic characteristics of foreign economic relations of both the region and the country as a whole has become more urgent. This is understandable, because the introduction of new elements into the national media can not avoid impact on existing economic order, affecting the interests of many sectors of society, on the other hand out of business structures for a national framework creates a different socio-economic aura of peace.

Socio-economic aspect of foreign economic relations development should become one of the most important strategic guiding lines. Possible socioeconomic effects of foreign economic transformation should be carefully calculated, possible ways, methods, techniques of smoothing (regulation) in relation to various facets of foreign models and emerging situations should be planned.

The main difference between the competitive advantages of regional managers of the country lies in the greater mobility of production factors. In the future openness of the economy of individual regions will increase, primarily due to integration into the world economy. Competition between re- 
gions, occurring in increased mobility of production factors will increase the dependence of export potential and interregional trade in the region by changing the competitive advantages of regions [4]. All these factors make the scientific community the task of theoretical and methodological quality, and methodological support for the challenges of globalization - the integration - localization - competitiveness.

Sverdlovsk region, despite the difficulties associated with the overall macroeconomic situation, is a dynamically developing region today, and Sverdlovsk enterprises continue to implement projects of modernization and development [1].

The strategic plan of Sverdlovsk region focuses on the innovative renewal of traditional sectors of the economy and structural diversification of the economy through innovative technology development.

An important element of a favorable investment climate is the new industrial infrastructure. To date, the basis of foreign trade in the region is exporting goods and services, exceeding imports by almost 3 times. Sverdlovsk region belongs to the subjects of the Russian Federation, which is actively involved in foreign economic activity. Foreign trade of Sverdlovsk region in the pre-crisis period (particularly in the last 10 years) has grown steadily - as with the CIS countries and with foreign countries (Fig. 1).

Decline in exports in 2009 was mainly due to lower cost in the supply of metals and products from it. The decline in imports in 2009 was due to reduction of supply of machine-building products, chemical products, etc.

Foreign trade turnover of Sverdlovsk region in 8 months of 2010 amounted to 5,373 million U.S. dollars, with 3,852 million dollars comes from exports, and 1521 million U.S. dollars for imports.

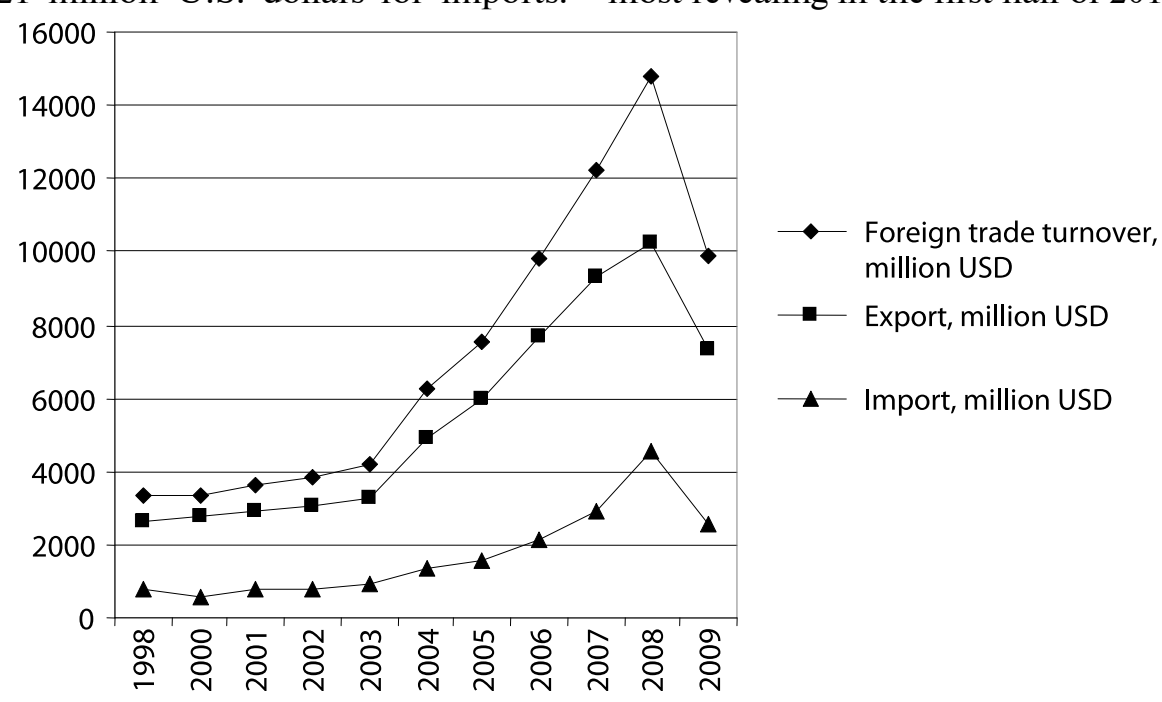

Fig. 1. The dynamics of foreign trade turnover of Sverdlovsk region in 1998-2009, million USD (at current prices)
Compared to the same period in 2009 export growth in value terms amounted to more than $30 \%$ (at current prices), growth in imports $-18 \%$. The nonCIS countries had $86,1 \%$ of total turnover ( 4.6 billion U.S. dollars), while the CIS countries - 13,9\% (731.6 million U.S. dollars). These statistics once again confirms that the decrease in foreign trade turnover of Sverdlovsk region in 2009 was due to the global financial and economic crisis and according to forecast estimates foreign trade turnover at the end of 2010 will be comparable with the turnover of the pre-crisis 2007-2008 period.

In the commodity structure of exports has traditionally dominated by black and nonferrous metals and its products, which share in January-June 2010 was $51 \%$. Also, a significant share of exports in the region has chemical products and rubber products (20\%). Deliveries to the export of machinery, equipment and vehicles amounted to $14 \%$ of total exports.

In the commodity structure of imports today machinery, equipment and vehicles (41\% of total imports), mineral products $(16 \%)$, chemical products $(15 \%)$, and also metals and its products $(12 \%)$ are dominated.

Sverdlovsk region today is one of the most investment-attractive regions and has an active policy to attract foreign investment. The overall dynamics of inflow of foreign capital is presented in Table.

In the first half of 2010, foreign investment increased by $27 \%$ compared to a year ago and amounted to 740 million U.S. dollars. In general, we can note that the rate of investment activity in 2010 reflects the state policy of attracting foreign investments and increase foreign investor interest in Sverdlovsk region.

In connection with this the amount of «other» investment (i. e. commercial and other loans) is the most revealing in the first half of 2010. Their overall 
Dynamics of foreign investments in Sverdlovsk region in 2000-2009, million USD

\begin{tabular}{|c|c|c|c|c|}
\hline year & total & direct & indirect & others \\
\hline 2000 & 163 & 74 & 0 & 90 \\
\hline 2003 & 1315 & 76 & 15 & 1224 \\
\hline 2004 & 517 & 63 & 2 & 452 \\
\hline 2005 & 1094 & 13 & 1 & 1079 \\
\hline 2006 & 1390 & 4 & 229 & 1157 \\
\hline 2007 & 1338 & 119 & 392 & 828 \\
\hline 2008 & 2114 & 345 & 5 & 1763 \\
\hline 2009 & 1366 & 88,0 & 11,2 & 1267,7 \\
\hline
\end{tabular}

growth in $12,6 \%$ compared to the first half of 2009 reflects the continued stabilization of the situation, including the credit markets.

The volume of portfolio investment 105 million USD was a distinctive feature of the first half of 2010 and this figure exceeded the level of 2009 more than 14 times. Activity in the stock market is certainly a prominent feature at the end of 2009, when companies began to enter the equity markets actively. Selling stakes in large regional enterprises of metallurgical production should be taken into account too. Metallurgical enterprises have received more than $65 \%$ of the total foreign investment in Sverdlovsk region.

The international migration has great importance in foreign trade activities of Sverdlovsk region as its component. Labour migration plays great role for the region. In 2009, the proportion of migrants who arrived from Ukraine, Kazakhstan and Central Asia in the total international migration has not changed in comparison with 2008 and amounted to $69.3 \%$ (in 2007 this share was slightly higher 73\%). Meanwhile, according to the Department of Public Employment Service of Sverdlovsk region 74.4 thousand unemployed was officially registered at the end of June 2010. Total unemployment was $6.7 \%$, registered $-3.1 \%$ of the economically active population. Thus, unemployment is low. Conversely, there is a shortage of labour, therefore, it is advisable to attract migrants from neighboring countries such as Kazakhstan or China, and highly qualified specialists for the transfer of expertise, for example from Europe.

Thus, by analyzing the foreign economic activity of Sverdlovsk region - its foreign trade, attracting foreign investment and migration policy, it is possible to conclude multi-directed foreign economic relations of the subject of the Russian Federation. In particular, the proven long-term partners of the region are located in Western Europe, among the high-tech developed countries such as Germany,

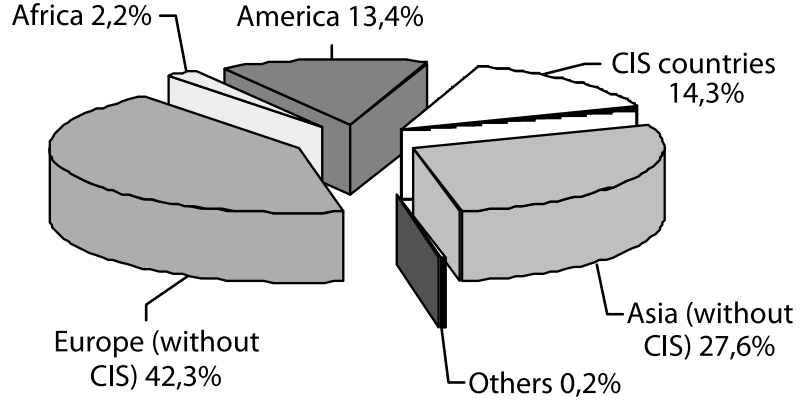

Fig. 2. Geography of exports of Sverdlovsk region in 2008

France, the Netherlands, the UK, Italy; also the CIS member states form important set of interests for the region, namely, Kazakhstan, on the border with which region spaced relatively close, and which is very similar to Russia's economic structure, and other Central Asian states, such as Tajikistan, Uzbekistan, which together with Kazakhstan and Russia are members of the Eurasian Economic Community (EEC) and the Shanghai Cooperation Organization (SCO); and Belarus - a member of the Union State of Russia and Belarus and the Eurasian Economic Community, Asian nations such as China and India, which, having a strong growing economies, are present in many areas of the world economy and maintain cooperation with almost all the world (Figure 2).

In the light of changing balance of forces in the system of world economic relations, we have to talk about «rising countries-giants», the largest and most powerful of which form the already mentioned BRIC group. In other words, the global situation recently drew attention to several major states which accumulate the prerequisites for the transition to a higher level in the global hierarchy despite past and current backlog, and start weighty influence on the formation of a world order. Russia, under transitivity of its economic system, the incomplete development of many market mechanisms and, at the same time, the huge economic potential, according to some estimates, is able to take the place of the nucleus of the BRIC. Taking into account that Russia is closely linked with Western Europe (as was noted above and shown in the example of Sverdlovsk region), it can perform a mediating function between developing countries (China, India, Brazil and others) and developed. Specifically, in economic vein, and specifically in the case of Sverdlovsk region, this will be reflected in the fact that it can become a transit region of many global economic processes. This can be expressed not only in the operation of largescale database of goods transshipment (as the region occupies an intermediate geographical position be- 
tween developed Europe and emerging Asia), but also in the establishment of investment and financial centers (exchanges, banks), re-training centers and language training of international working forces, etc. While such perspectives are only theoretically possible, the desire for them step by step implementation will contribute to the economic development of Sverdlovsk region.

Among this group of countries, special attention should be paid to the People's Republic of China (PRC). International economic relations of Sverdlovsk region with the provinces of China become stronger from year to year, trade turnover, the volume of capital flows, foreign investment, exchange of educational purposes are growing, economic and technological cooperation is developing, the amount of labour migration is increasing. Sverdlovsk region, being at the crossroads of Europe and Asia, feels Eurasian challenges directly and should respond to that need without delay and every day. China factor in these challenges plays not last role, and in this connection it is actively included in the foreign economic strategy of the region. Today, the volume of exports to China exceeds the volume of imports. Ural and Chinese industrial enterprises have maintained close economic ties. For example, in 2008 machine building corporation «Uralmash» signed an agreement with a group of heavy engineering industry in Guangzhou; Ural Optical and Mechanical Plant was opened in China subsidiary to produce geodetic instruments. Therefore, cooperation between Sverdlovsk region and China should move forward. The main priorities in the development of foreign economic relations of Sverdlovsk region and provinces of China should be:

- Joint development and introduction of high technologies;

- Attracting Chinese investment in the economy of Sverdlovsk region;

- Cooperation in the fields such as energy conservation, wood processing, mechanical engineering;

- Development of education, exchange of experience and knowledge.

Continuation of dynamic development of foreign and international relations, set in the previous years, the strengthening of international prestige and influence of Sverdlovsk region in the world arena are the key objectives in the strategy of foreign economic activity in the region against the background of global economic growth taking into account the guidelines of the foreign trade of the Russian Federation contained in the concept of long-term socio-economic development of Russia. In this connection it is necessary to accomplish the following tasks:
1. Improving the competitiveness of domestic goods in domestic and overseas markets.

2. Improving the investment climate in the region, creating favorable conditions for attracting foreign investment in economy.

3. Establishment of schemes of direct exportimport operations with foreign countries.

4. Appearance of enterprises of Sverdlovsk region in the world's major stock exchanges.

Thus, in terms of socio-economic approach foreign economic relations are a tool to improve the socio-economic development and regional competitiveness. It is not only the foreign trade turnover, which increases the volume of industrial production, fiscal duties and the completion of the budget, but the ability to attract foreign investment in the creation of high-tech industries, to attract advanced foreign experience professionals, seek new markets for products with high added value and new ideas to create the infrastructure for small and medium-sized businesses.

One of the projects aimed at increasing the proportion of products with high added value in the production structure is a project to create a special economic zone «Titanium Valley». There will be projects to develop the production base of raw titanium, production of semi-finished products from titanium for use in various industries, parts and components for the aerospace industry. This will create a special machine-building complex that will work in the manufacture of titanium equipment for chemical, aviation and railway engineering, ferrous metallurgy and nuclear power. At the moment, according to the Government report, five corporations - Arvi, SR Systematics, Mashprom, United Aircraft Corporation and MAG - are willing to sign an agreement of intention to obtain residence status (totally more than 25 companies confirmed the interest to the project). The company even with 100 percent foreign capital can take participation in the FEZ (free economic zone). Taxes on property, land and transportation will not be levied from residents, and profit tax rate will be reduced from $20 \%$ to $15.5 \%$. In addition, «Titanium Valley» will have the status of a free customs zone; residents will have the right to import foreign goods without paying customs duties and VAT, as well as other benefits. In this case, according to preliminary estimates, by 2030 the project is to bring the budgets of all levels of 179 billion rubles. Project of this kind can really lead the region to new and more advanced position on the national and global levels [5].

In regional economy there are already a number of studies confirming the positive impact of foreign 
economic relations of the region on its socio-economic development [2]. Open trade policy in China, Australia allowed them to increase the pace of economic growth within a few decades, to change the structure of production and consumption, improve it and bring to Western standards of quality and efficiency. Russian regions are also not an exception from global trends. Today Ural is a part of the world economic space, but the structure of its foreign economic relations remained still with a negative trend to increased raw material export specialization. Therefore, the solution of tasks of regional development will allow using the external economic relations more effectively and efficiently. The integration of regions into the world economy is effective in the case when consumers prefer domestic products, and manufacturers are able to offer to foreign markets competitive products highly processed or highvalue-added. Then the use of foreign economic relations will lead to improving competitiveness, increasing production, employment, growing of incomes and, consequently, to growing of budget revenues in the region, rising of purchasing power, which in turn leads to the development of trade, transport, services and culture and, ultimately, to improve the level and quality of life. Therefore, today it is important to highlight the following areas of regional foreign policy: changing the structure of production towards high-tech products, development of transport and logistics infrastructure, attracting foreign investment, the creation and strengthening of inter- regional relations. All this will favour the competitiveness of Sverdlovsk region at the national level, the harmonious integration into the world economy and creating conditions for advantageous social and economic development.

\section{References}

1. Andreeva E. L. The organizational structures of firms in the context of globalization: the manual / E. L. Andreeva. Yekaterinburg: Ural state. econ. univ., 2003. - $242 \mathrm{pp}$.

2. Kapustina L. M. Region in the global and national economic space. Ekaterinburg: Ural Branch of RAS, 2000. $360 \mathrm{pp}$.

3. Foreign economic activity of enterprise: a textbook for university students studying economics / L. E. Strovsky and others. - 4th issue, revised and add. - M.: UNITY-DANA, 2007. - 799 pp.

4. Region in the new paradigm of spatial organization of Russia / Ed. by A. I. Tatarkin; RAS, Ural Branch, Institute of Economics. - Moscow: ZAO Publishing House «Economics», 2007. - $751 \mathrm{pp}$.

5. Parfentyeva I. I. Titanium Valley has been legalized / Kommersant.ru: news online. url: http://www/kommersant. $\mathrm{ru} /$ doc.aspx?DocsID $=1561989 \&$ NodesID $=4$ (date of access 21.12.2010).

6. Analyzing socioeconomic inequalities within the context of 20 years of national economic system transformations / Edited by Academician Alexander Tatarkin. Ekaterinburg: Publishing house of Institute of Economics (Ural branch of Russian academy of science), 2010.213 p.

U.D.C. 339.9(1)

keywords: globalization, foreign economic relations, regional competitiveness, socio-economic development, Sverdlovsk region

\section{ПРЕИМУЩЕСТВА ЮГА РОССИИ ПРИ АКТИВИЗАЦИИ УЧАСТИЯ В НАЦИОНАЛЬНЫХ И МИРОХОЗЯЙСТВЕННЫХ ПРОЦЕССАХ}

C. C. Рeшues

В статье определены преимущества Юга России как объекта активизации участия в национальных и мирохозяйственных процессах в условиях развития глобализации и регионализации мировой экономики. При правильном их использовании Юг России встанет на путь устойчивого роста и развития, полноценно интегрируется в единое социально-экономическое пространство страны и внешнеэкономические процессы.

Юг России последние десятилетия ассоциируется в основном с такими понятиями, как «крупнейшая сельскохозяйственная житница» и «богатейший курортно-оздоровительный комплекс страны», развитие которых всегда считалось приоритетным направлением социально-экономической политики государства. Однако этими приоритетными направлениями заметный вклад Юга России в национальную экономику не ограничивается: на протяжении уже нескольких десятилетий он занимает существенное место в реализации крупных общенациональных проектов в области сельхозмашиностроения, электровозостроения, энергетического машиностроения, 
development of the Urals in the 19-20 centuries. Ekaterinburg 2000. 104 pp.

4. Population policies in the region: problems and prospects / [text]: sb. st. Under. Ed. Doctor of Sociology, prof. A. Kuzmin / Institute of Economics, UB RAS, 2010. 196.

5. Dmitriev A. V., Poduhov G. A. The receiving society: the practice of interaction with immigrants. // Sotsis. 2009. (№ 10)

6. Debt Victor. Have exhausted the quota // Rossiyskaya Gazeta. 2009. December 17 (№ 5066).

7. Rybakovsky L. L. Migration potential. Concept and criteria of evaluation. // Sotsis. 2009. (№ 2)
8. Rybakovsky L. L. Comparative evaluation of a demographic crisis of Russian regions // Sotsis. 2008. (№ 10)

9. Site Goskomstat of Russia [electronic resource]. URL: http://www.gks.ru.

10. Sverdlovsk Oblast Duma website [electronic resource]. URL: http://www.duma.midural.ru.

\section{U.D.C. 314.143 (1)}

keywords: migration, population, migration gain, migration dynamics, migration links 